\title{
Antifungal activities of the essential oil and its fractions rich in sesquiterpenes from leaves of Casearia sylvestris Sw.
}

\author{
FLAVIANE G. PEREIRA ${ }^{1}$, RONALDO MARQUETE ${ }^{2}$, LEVY T. DOMINGOS ${ }^{3}$, MARCO E.N. ROCHA ${ }^{4}$, \\ ANTONIO FERREIRA-PEREIRA ${ }^{3}$, ELISABETH MANSUR ${ }^{5}$ and DAVYSON L. MOREIRA ${ }^{4}$ \\ ${ }^{1}$ Programa de Pós-Graduação em Biotecnologia Vegetal e Bioprocessos, Universidade Federal do Rio \\ de Janeiro, Avenida Carlos Chagas Filho, 373, Edifício do Centro de Ciências da Saúde, Bloco K, $2^{\circ}$ \\ andar, sala K 032, Cidade Universitária, Ilha do Fundão, 21941-902 Rio de Janeiro, RJ, Brazil \\ ${ }^{2}$ Fundação Instituto Brasileiro de Geografia e Estatística, Diretoria de Geociências, Avenida \\ República do Chile, 500, $15^{\circ}$ andar, Centro, 20031-170 Rio de Janeiro, RJ, Brazil \\ ${ }^{3}$ Instituto de Microbiologia Professor Paulo de Góes, Departamento de Microbiologia Geral, Universidade \\ Federal do Rio de Janeiro, Avenida Carlos Chagas Filho, 373, Edifício do Centro de Ciências da Saúde, Bloco \\ I, $1^{\circ}$ andar, sala I044, Cidade Universitária, Ilha do Fundão, 21941-902 Rio de Janeiro, RJ, Brazil \\ ${ }^{4}$ Fundação Oswaldo Cruz, Departamento de Produtos Naturais, Instituto de Tecnologia Fármacos, \\ Farmanguinhos, Rua Sizenando Nabuco, 100, Manguinhos, 21040-900 Rio de Janeiro, RJ, Brazil \\ ${ }^{5}$ Universidade do Estado do Rio de Janeiro, Instituto de Biologia Roberto Alcantara Gomes, Departamento de Biologia \\ Celular, Rua São Francisco Xavier, 524, sala 505 PHLC, Maracanã, 20550-013 Rio de Janeiro, RJ, Brazil
}

Manuscript received on May 15, 2017; accepted for publication on August 7, 2017

\begin{abstract}
Casearia genus (Salicaceae) is found in sub-tropical and tropical regions of the world and comprises about 160-200 species. It is a medicinal plant used in South America, also known as "guaçatonga", "erva-detiú", "cafezinho-do-mato". In Brazil, there are about 48 species and 12 are registered in the State of Rio de Janeiro, including Casearia sylvestris Sw. There are many studies related to the chemical profile and cytotoxic activities of extracts from these plants, although few studies about the antifungal potential of the essential oil have been reported. In this work, we have studied the antifungal properties of the essential oil of $C$. sylvestris leaves, as well as of their fractions, against four yeasts (Saccharomyces cerevisae, Candida albicans, C. glabrata and C. krusei) for the first time. The chemical analysis of the essential oil revealed a very diversified ( $\mathrm{n}=21$ compounds) volatile fraction composed mainly of non-oxygenated sesquiterpenes (72.1\%). These sesquiterpenes included $\alpha$-humulene (17.8\%) and $\alpha$-copaene $(8.5 \%)$ and the oxygenated sesquiterpene spathulenol $(11.8 \%)$ were also identified. Monoterpenes were not identified. The fractions are mainly composed of oxygenated sesquiterpenes, and the most active fraction is rich in the sesquiterpene 14-hydroxy -9-epi- $\beta$-caryophyllene. This fraction was the most effective in inhibiting the growth of three yeast strains.
\end{abstract}

Key words: Candida sp., Casearia genus, essential oil, medicinal plant, Saccharomyces cerevisae.

Correspondence to: Flaviane Gomes Pereira

E-mail: flaviane.gp@gmail.com 


\section{INTRODUCTION}

Casearia genus belongs to Salicaceae family, and it is distributed in sub-tropical and tropical regions of the world, comprising 200 species. The genus is found in the Americas, Africa (rarely), Asia and Australia (Sleumer 1980, Mosaddik et al. 2004, Breteler 2008). In Brazil, there are about 48 species, 24 of which are endemic, and 12 species are registered in the State of Rio de Janeiro (Marquete and Vaz 2007, Marquete and Mansano 2010).

Casearia sylvestris Sw. can be found throughout the Brazilian territory. It is popularly known as "guaçatonga", "tiư" or "erva-de-lagarto", and has medicinal properties according to ethnobotanical surveys (Bratti et al. 2013, Pinto et al. 2013, Tomazi et al. 2014). This plant is also included in the public health system (SUS) of Brazil and widely used to treat different diseases. According to Sato et al. (1996), the chemical components found in essential oils and extracts from leaves of $C$. sylvestris can be related to their uses in folk medicine as an antiseptic, antimicrobial and antiviral (Esteves et al. 2005, Pereira et al. 2016).

The secondary metabolites of Casearia are mainly diterpenes, specially the clerodane type (Kanokmedhakul et al. 2007, Carvalho et al. 2009, Ferreira et al. 2010). The essential oils of this genus are rich in monoterpenes and sesquiterpenes (Tininis et al. 2006, Sousa et al. 2007, Silva et al. 2008, Pereira et al. 2017), and some of the main compounds already identified are $\alpha$-zingiberene, $\alpha$-humulene, caryophyllene, and bicyclogermacrene (Esteves et al. 2005, Bou et al. 2013).

In spite of the several phytochemical studies on $C$. sylvestris, the chemical profile and the antifungal activity of essential oils have not been studied so far. It seems sesquiterpenes may play an important role as antifungal agents, and considering the possibility of further studies, non-oxygenated sesquiterpenes such $\alpha$-humulene found in Casearia species can be investigated (Pereira et al. 2017).
Fungal diseases are a menacing problem in the world, affecting mainly immunocompromised patients (Cannon et al. 1995, 2009). The genus Candida is the most common agent diagnosed in invasive fungal infections, with high rates of morbidity and mortality. This pathogen is frequently isolated from patients in critical health condition, and is among leading causes of bloodstream and catheter-associated urinary tract infections (Lockhart 2014). Candida albicans strains are found in healthy individuals, including C. glabrata, C. tropicalis and C. krusei, albeit they are also opportunistic pathogens (Procop and Roberts 2004, Pfaller et al. 2008). Resistance of Candida yeast to current medications, including the class of azoles, has been reported (Pfaller and Diekema 2004, Pfaller 2012), and one of the causes of this resistance is the overexpression of plasma efflux pumps (Holmes et al. 2008, Sanglard and Bille 2002, Rogers and Barker 2003, Cannon et al. 2009).

In view of these facts, studies of biologically active molecules from plants which can play an important role as an alternative antifungal compound or in association with antifungal drugs, are highly recommended. It is important to note that both extracts and essential oils of several species have been shown to possess potent antifungal activity (Cruz et al. 2007, Kalidindi et al. 2015).

Development of new therapeutic approaches may contribute for the treatment of diseases caused by fungi because the resistance to existing drugs is a serious complication for patients (Pfaller et al. 2005, Pfaller and Diekema 2007). This study shows that sesquiterpenes with basic caryophyllene skeleton derived from $C$. sylvestris might be used in association with the current antifungal drugs to treat Candida infections. 


\section{MATERIALS AND METHODS}

Casearia sylvestris Sw. (Salicaceae) was collected in Tijuca National Park (S22 57'05.04" W43 ${ }^{\circ} 17^{\prime} 10.09$ "), Rio de Janeiro, Brazil (SISBIO license n. 38765-1/CGEN license n. 010105/2014$0)$. Plant identification was performed by Dr. Ronaldo Marquete, and the herbarium voucher was deposited in the Botanical Garden Herbarium of Rio de Janeiro with registration number RB 570651.

Fresh leaves of C. sylvestris $(1.5 \mathrm{~kg})$ were cut to small pieces and submitted to hydrodistillation in a modified Clevenger-type apparatus for two hours. Essential oil was directly separated from the aqueous phase yielding $1.2 \%(\mathrm{w} / \mathrm{v})$, transferred to amber flasks and kept at low temperature $\left(-20^{\circ} \mathrm{C}\right)$ until analysis. The sample was subjected to analysis by gas chromatography coupled to flame ionization detector (HP-Agilent 6890 GC-FID) and by gas chromatography coupled to mass spectrometry (HP Agilent GC 6890 - MS 5973), at the Analytical Platform of Institute of Pharmaceutical Technology (Farmanguinhos) Oswaldo Cruz Foundation (Rio de Janeiro, Brazil), as described previously (Pereira et al. 2016). Briefly, the essential oil was diluted in dichloromethane $(1.0 \mathrm{mg} / \mathrm{ml})$ and analyzed by GC-MS to obtain the mass spectra and to perform chemical characterization. Concomitantly, another sample of essential oil $(0.5 \mathrm{mg} / \mathrm{ml})$ was analyzed by GC-FID for quantification of chemical constituents and to determine the retention indices (RI). The relative abundance of each essential oil component in the sample was quantified based in the individual relative peak area in the chromatogram. The substances in the essential oil were identified by comparing their mass spectra with database registration (WILEY7n) and by comparison of calculated Retention Indices (RI) with those from the literature (Adams 2001). RI were calculated from GC data of a homologous series of saturated aliphatic hydrocarbons within C8 to C20 (Sigma-
Aldrich), performed using the same column and conditions adopted in the GC analysis for the essential oils, and with the equation proposed by Vandendool and Kratz (1963).

The parameters adopted for HP-5MS were (5\% diphenyl and 95\% dimethylpolysiloxane), column $(30 \mathrm{~m} \times 0.32 \mathrm{~mm}$ i.d. $\times 0.25 \mu \mathrm{m}$ particle size), temperature programming from 60 to $240^{\circ} \mathrm{C}$, with increase of $3^{\circ} \mathrm{C} / \mathrm{min}$, using synthetic air and hydrogen as the carrier gases, with a flow rate of $1 \mathrm{ml} / \mathrm{min}$ and injection volume of $1 \mu \mathrm{l}$. For GCMS, the parameters used for HP-5MS were (5\% diphenyl and $95 \%$ dimethylpolysiloxane), column $(30 \mathrm{~m} \times 0.32 \mathrm{~mm}$ i.d. $\times 0.25 \mu \mathrm{m}$ particle size $)$, temperature programming from 60 to $240^{\circ} \mathrm{C}$, with increase of $3^{\circ} \mathrm{C} / \mathrm{min}$, using helium as the carrier gas, with a flow rate of $1 \mathrm{ml} / \mathrm{min}$ and injection volume of $1 \mu \mathrm{l}$ (Pereira et al. 2017).

For the phytochemical analysis of the major essential oil compound, the extraction of essential oil of C. sylvestris fresh leaves yielded around 20 $\mathrm{mL}$ of a pure, clear, fluid and yellowish collored oil. Part of the oil ( $2 \mathrm{~mL})$ was submitted to a silica gel chromatographic column, which was eluted by n-hexane, ethyl acetate and methanol and their mixtures, using an increasing polarity gradient. The chromatographic running was very slow as well as the increasing polarity of solvent systems, and 99 fractions were obtained. After analysis by TLC plates under UV wavelength, the fractions were reunited according to their similarity, resulting into 11 fractions $(1-6 ; 7-10 ; 11-13 ; 14-28 ; 29-56 ; 57-$ $62 ; 63-80 ; 87-88 ; 91-93 ; 94-96 ; 97-98)$. The 11 fractions were analyzed by GC-MS under the same conditions used for the pure essential oil sample.

The MIC of total oil and fractions was determined by a microdilution method in 96-well microplates. Yeasts were inoculated in YPD or RPMI medium $(200 \mu \mathrm{l})$ at a final concentration of $1 \times 10^{4}$ or $2,5 \times 10^{3}$ cells per well for Saccharomyces cerevisiae and Candida sp., respectively, in the presence of a series of twofold dilutions of each 
compound starting at 250 to $0.9 \mu \mathrm{g} / \mathrm{ml}$. Microplates were incubated at 30 or $37^{\circ} \mathrm{C}$ for $48 \mathrm{~h}$ using an orbital shaker $(100 \mathrm{rpm})$. Cell growth was measured at $600 \mathrm{~nm}$ with a microplate reader FLUOstar Optima (BMG Labtech, Germany) relative to the control.

\section{RESULTS}

GC-MS analysis allowed the characterization of 21 compounds, comprising $98.2 \%$ of the pure essential oil from leaves of $C$. sylvestris. The main compounds identified were $\alpha$-humulene (17.8 $\%)$, spathulenol (11.8\%), and $\alpha$-copaene (8.5\%). Monoterpenes were not found. The essential oil is richer in non-oxygenated sesquiterpenes $72.1 \%$ and $25.6 \%$ of oxygenated sesquiterpenes. The fraction 1-6 presented mainly oxygenated sesquiterpenes, and 15 compounds could be identified, comprising $83.7 \%$ of the essential oil. The main compounds found were $\alpha$-copaene ( $8.52 \%$ ), caryophyllene oxide $(11.60 \%)$, and 14-hydroxy-9-epi- $\beta$-caryophyllene (18.09\%). The fractions 7-10, 11-13, 57-62 and 9193 were less rich in non-oxygenated sesquiterpenes. With respect to fractions 7-10, 11-13, 29-56, 57-62 and 91-93 the main compounds were oxygenated sesquiterpenes, comprising more than $40 \%$ of the essential oil (Table SI - Supplementary Material).

The antifungal activity of the pure essential oil and their fractions was evaluated using different concentrations $(5,25,50,100$ and $250 \mu \mathrm{g} / \mathrm{mL}$ ), according to the zone of inhibition of microorganisms (Tables II and III). According to $\mathrm{IC}_{50}$ values, the most sensitive strains were C. glabrata and S. cerevisiae. However, it was observed that the pure essential oil (C. krusei $\mathrm{IC}_{50}$ $74.3 \mu \mathrm{g} / \mathrm{mL})$ and fraction 1-6 (S. cerevisiae $\mathrm{IC}_{50}$ $23.3 \mu \mathrm{g} / \mathrm{mL}$ ) were more effective in inhibiting the growth of these strains (Tables II and III).

\section{DISCUSSION}

Studies on the pharmacological potential of $C$. sylvestris are mainly related to antitumor, antiinflammatory and antiviral activities (Esteves et al. 2005, Ferreira et al. 2016, Pereira et al. 2016), on the other hand antifungal activities were comparatively less investigated. In addition, there are no studies on the potential of the essential oil and its fractions.

The essential oil of $C$. sylvestris is rich in sesquiterpenes, regardless of the region in which the plants are found (Tininis et al. 2006, Silva et al. 2008, Esteves et al. 2005, Bou et al. 2013). Monoterpenes can also be identified, but not in significant amounts (Sousa et al. 2007, Stefanello et al. 2010). The potential of terpenes for the treatment of candidiasis has been reported previously (Dalleau et al. 2008, Martínez et al. 2014)

TABLE II

Antifungal activities of the essential oil and its fractions from fresh leaves of Casearia sylvestris (IC ( $_{0}$ values).

\begin{tabular}{lcccc}
\hline Samples & $\begin{array}{c}\text { Saccharomyces cerevisiae } \\
\text { (Wild type) }\end{array}$ & $\begin{array}{c}\text { Candida albicans } \\
\text { (ATCC 10231D-5) }\end{array}$ & $\begin{array}{c}\text { Candida glabrata } \\
\text { (ATCC 2001D-5) }\end{array}$ & $\begin{array}{c}\text { Candida krusei } \\
\text { (ATCC 20298) }\end{array}$ \\
\hline Pure oil & 88.5 & $>250$ & 83.1 & 74.3 \\
Fraction 1-6 & 23.3 & 97.2 & 73.5 & 160.9 \\
Fraction 7-10 & 166.3 & $>250$ & $>250$ & 158.9 \\
Fraction 11-13 & $>250$ & $>250$ & $>250$ & 173.3 \\
Fraction 14-28 & 93.1 & $>250$ & 123.5 & 149.5 \\
Fraction 29-56 & 182.9 & $>250$ & $>250$ & 196 \\
Fraction 57-62 & 226.5 & $>250$ & 160.2 & $>250$ \\
Fraction 87-88 & 85.6 & 169.5 & 145.4 & 165.1 \\
Fraction 91-93 & 151.2 & $>250$ & & $>250$ \\
\hline
\end{tabular}


TABLE III

Antifungal activities of the essential oil and its fractions from fresh leaves of Casearia sylvestris (MIC values).

\begin{tabular}{lcccc}
\hline Samples & $\begin{array}{c}\text { Saccharomyces cerevisiae } \\
\text { (Wild type) }\end{array}$ & $\begin{array}{c}\text { Candida albicans } \\
\text { (ATCC 10231D-5) }\end{array}$ & $\begin{array}{c}\text { Candida glabrata } \\
\text { (ATCC 2001D-5) }\end{array}$ & $\begin{array}{c}\text { Candida krusei } \\
\text { (ATCC 20298) }\end{array}$ \\
\hline Pure oil & 125 & $>250$ & 125 & 125 \\
Fraction 1-6 & 62.5 & $>250$ & 125 & 250 \\
Fraction 7-10 & 250 & $>250$ & $>250$ & 250 \\
Fraction 11-13 & $>250$ & $>250$ & $>250$ & 250 \\
Fraction 14-28 & 125 & $>250$ & 250 & 250 \\
Fraction 29-56 & 250 & $>250$ & $>250$ & $>250$ \\
Fraction 57-62 & $>250$ & $>250$ & 250 & $>250$ \\
Fraction 87-88 & 125 & 250 & $>250$ & 250 \\
Fraction 91-93 & 250 & $>250$ & & $>250$ \\
\hline
\end{tabular}

In the present work it was observed that both pure essential oil and fraction 1-6 are rich in non-oxygenated and oxygenated sesquiterpenes. The major component of the pure essential oil is the non-oxygenated sesquiterpene $\alpha$-humulene, which is not present in fraction 1-6, in which the major component is the oxygenated sesquiterpene 14-hydroxy-9-epi- $\beta$-caryophyllene.

It is relevant to note that sesquiterpenes are difficult to be separated into each component and they are usually co-eluted with another sesquiterpenes in the mixture, for instance the non-oxygenated sesquiterpene aromadendrene is present in large quantities in fraction 29-56, but it is absent in other five fractions. In addition, there are many similar components in the essential oil and the same component has several matches in the mass spectral database. Another important remark is related to the frequency of co-eluting components which are identified in the GC column and consequently their spectra are combined.

Both pure essential oil and fraction 1-6 were active against $S$. cerevisiae and $C$. glabrata. This activity may be represented by the group of three substances identified in both samples, such as $\alpha$-copaene, spathulenol and caryophyllene oxide. Possibly these three substances act synergistically. The other fractions, whose major components were not the sesquiterpenes $\alpha$-humulene and 14-hydroxy-9-epi- $\beta$-caryophyllene did not display relevant inhibitory activity.

The strains S. cerevisae, C. glabrata and $C$. krusei were the most susceptible to pure essential oil whose major compound is $\alpha$-humulene; on the other hand, the fraction 1-6 rich in the oxygenated sesquiterpene14-hydroxy-9-epi- $\beta$-caryophyllene was more active against the strains $S$. cerevisae and C. glabrata. Both compounds present the basic skeleton of the byciclic sesquiterpene caryophyllene, and there are studies which identified essential oils containing sesquiterpenes $\beta$-caryophyllene and $\beta$-caryophyllene oxide as an alternative therapy for candidiasis (Asdadi et al. 2015). Moreover, sesquiterpenes may act inhibiting the formation of hyphae of $C$. albicans (Xie et al. 2015). In fact, the essential oils rich in caryophyllene and its isomers ( $\beta$-caryophyllene and $\alpha$-humulene) have antimicrobial and antifungal activities (Sabulal et al. 2006). In addition, sesquiterpenes $\beta$-caryophyllene and caryophyllene oxide may be absorbed by the fungal cell membrane and act as antifungal agent by releasing lipophilic drugs (Sarpietro et al. 2015). According to the work of Khan et al. (2014), essential oils of Ocimun sanctum play a crucial role in the 
secretion of hydrolytic enzymes responsible for the virulence of $C$. albicans.

Oxygenated sesquiterpenes might not represent an important role as a potent antifungal in Saccharomyces and Candida strains, because even high concentrations of caryophyllene oxide (fractions 7-10 and 11-13), humulene epoxide and spathulenol (fraction 57-62), viridiflorol and spathulenol (fraction 87-88), viridiflorol and $\alpha$-muurolol (fraction 91-93) have not achieved significant activity against these strains. On the other hand, studies conferred the importance of polar compounds such as $\beta$-caryophyllene oxide, in terms of disrupting the fungal cell membrane (Sarpietro et al. 2015).

There are many studies over the last 20 years that demonstrated the relevance of terpenes in fungal cell permeability associated with changes in the properties of fungal membranes and their functions (Sikkema et al. 1995, Lambert et al. 2001, Grande-Tovar et al. 2016, Kumar et al. 2016). Terpenes are also related to disorders of mitochondrial membrane in Candida species (Bakkali et al. 2008, Zuzarte et al. 2011).

Furthermore, fungal lipid bilayers are related to resistance, such as reduction of the amount of plasma membrane ergosterol, biofilm resistance and also release of extracellular vesicles. Hence, molecules that cause conformational changes in the integrity of fungal membranes may help in rational drug design (Cannon et al. 2009, Rella et al. 2016).

Considering the number of antifungal agents, only few classes of new drugs are available for the treatment of mucosal and systemic infections by Candida species. For instance, echinocandins, polyenes (amphotericin B), nucleoside analogs and other agents responsible for the inhibition of ergosterol biosynthesis, such as imidazoles and allylamines (Cannon et al. 2009). However, fungal resistance to current drugs over the last 30 years have led to a significant morbidity and mortality of the population, and drugs such fluconazol and itraconazole have been widely used for the treatment of systemic disease (Pfaller and Diekema 2007). Therefore, research based on new molecules from natural source, including terpenes, can be an alternative to design multifunctional drugs for the treatment of fungal infections.

We can conclude that pure essential oil rich in non-oxygenated sesquiterpene $\alpha$-humulene as well as its fraction rich in the oxygenated sesquiterpene14-hydroxy-9-epi- $\beta$-caryophyllene presented a good action against fungi, and further studies are necessary to investigate how sesquiterpenes may act as important antifungal agents.

\section{ACKNOWLEDGMENTS}

We would like to thank Conselho Nacional de Desenvolvimento Científico e Tecnológico (CNPq) and Fundação Carlos Chagas Filho de Amparo à Pesquisa do Estado do Rio de Janeiro (FAPERJ) for their financial support.

\section{REFERENCES}

ADAMS RP. 2001. Identification of Essential Oil Components by Gas Chromatography/Quadrupole Mass Spectroscopy. $3^{\text {rd }}$ ed., (Carol Stream, Allured Publishing).

ASDADI A, HAMDOUCH A, OUKACHA A, MOUTAJ R, GHARBY S, HARHAR H, El HADEK M, CHEBLI B AND IDRISSI HASSANI LM. 2015. Study on chemical analysis, antioxidant and in vitro antifungal activities of essential oil from wild Vitex agnus-castus L. seeds growing in area of Argan Tree of Marocco against clinical strains of Candida responsible for nosocomial infections. J Med Mycol 25(4): 118-127.

BAKKALI F, AVERBECK S, AVERBECK D AND IDAOMAR M. 2008. Biological effects of essential oils a review. Food Chem Toxicol 46: 446-475.

BOU DD, LAGO JH, FIGUEIREDO CR, MATSUO AL, GUADAGNIN RC, SOARES MG AND SARTORELLI P. 2013. Chemical composition and cytotoxicity evaluation of essential oil from leaves of Casearia sylvestris, its main compound $\alpha$-zingiberene and derivatives. Molecules 18(8): 9477-9487.

BRATTI C, VIEIRA M, ZÁRATE NAH, OLIVEIRA APA, MARAFIGA BG AND FERNANDES SSL. 2013. Levantamento de plantas medicinais nativas da Fazenda 
Azulão em Dourados - MS. Rev Bras Plantas Med 15(4I): 675-683.

BRETELER FJ. 2008. A synopsis of Casearia Jacq. (Samydeae - Salicaceae) in West and Central Africa of a description of new species from Eastern Congo (Kinshasa). Kew Bull 63: 101-112.

CANNON RD, LAMPING E, HOLMES AR, NIIMI K, BARET PV, KENIYA MV, TANABE K, NIIMI M, GOFFEAU A AND MONK BC. 2009. Efflux-mediated antifungal drug resistance. Clin Microbiol Rev 22(2): 291-321.

CANNON RDA, HOLMES AB AND MONK BC. 1995. Oral Candida clearance, colonization, or candidiasis? J Dent Res 74: 1152-1161.

CARVALHO ES, SANTOS AG AND CAVALHEIRO AJ. 2009. Identificação de diterpenos clerodânicos em diferentes órgãos de Casearia sylvestris Swartz. Rev Ciên Farm Básica Apl 30(3): 277-284.

CRUZ MC, SANTOS PQ, BARBOSA AM, MELO DL, ALVIANO CS, ANTONIOLLI AR, ALVIANO DS AND TRINDADE RC. 2007. Antifungal activity of Brazilian medicinal plants involved in popular treatment of mycoses. J Ethnopharmacol 111(2): 409-412.

DALLEAU S, CATEUA E, BERGES T, BERJEAUD JM AND IMBERT C. 2008. In vitro activity of terpenes against Candida biofilms. Int J Antimicrob Agents 31(6): 572-576.

ESTEVES ET AL. 2005. Gastric antiulcer and antiinflamatory activities of the essential oil from Casearia sylvestris Sw. J Ethnopharmacol 101: 191-196.

FERREIRA PMP ET AL. 2016. Preclinical anticancer effectiveness of a fraction from Casearia sylvestris and its component Casearin $\mathrm{X}$ : in vivo and ex vivo methods and miscroscopy examinations. J Ethnopharmacol 186: 270-279.

FERREIRA PMP ET AL. 2010. Casearin X exhibits cytotoxic effects in leukemia cells triggered by apoptosis. Chem Biol Interact 188: 497-504.

GRANDE-TOVAR CD, CHAVES-LOPEZ C, VIUDAMARTOS M, SERIO A, DELGADO-OSPINA J, PEREZALVAREZ JA, OSPINA N, LA TORA S, PALMIERI S AND PAPARELLA A. 2016. Sub-lethal concentrations of Colombian Austroeupatorium inulifolium (H.B.K.) essential oil and its effect on fungal growth and the production of enzymes. Ind Crops Prod 87: 315-323.

HOLMES AR, LIN YH, NIIMI K, LAMPING E, KENIYA M, NIIMI M, TANABE K, MONK BC AND CANNON D. 2008. ABC transporter Cdr1p contributes more than Cdr2p does to fluconazole efflux in fluconazole resistant Candida albicans clinical isolates. Antimicrob Agents Chemother 52: 3851-3862.

KALIDINDI N, THIMMAIAH NV, JAGADEESH NV, NANDEEP R, SWETHA S AND KALIDINDI B. 2015. Antifungal and antioxidant activities of organic and aqueous extracts of Annona squamosa Linn. Leaves. J Food Drug Anal 23(4): 795-802.
KANOKMEDHAKUL S, KANOKMEDHAKUL K AND BUAYAIRAKSA M. 2007. Cytotoxic clerodane diterpenes from fruits of C. grewiifolia. J Nat Prod 70: 1122-1126.

KHAN A, AHMAD A, XESS I, KHAN LA AND MANZOOR N. 2014. Ocimun sanctum essential oil inhibits virulence attributes in Candida albicans. Phytomedicine 21(4): 448452.

KUMAR KN, VENKATARAMANA M, ALLEN JA, CHANDRANAYAKA S, MURALI HS AND BATRA HV. 2016. Role of Curcuma longa L. essential oil in controlling the growth and zearalenone production of Fusarium graminearum. LWT - Food Sci Technol 69: 522-528.

LAMBERT RJW, SKANDAMIS PN, COOTE PJ AND NYCHAS GJE. 2001. A study of the minimum inhibitory concentration and mode of action of oregano essential oil, thymol and carvacrol. J Appl Microbiol 91(3): 453-462.

LOCKHART SR. 2014. Current epidemiology of Candida infection. Clin Microbiol Newslet 36(17): 131-136.

MARQUETE R AND MANSANO VF. 2010. A new species of Casearia (Salicaceae) from Southeastern Brazil. Novon (Saint Louis, Mo) 20: 179-181.

MARQUETE R AND VAZ ASF. 2007. O gênero Casearia no Estado do Rio de Janeiro, Brasil. Rodriguésia 58: 705-738.

MARTÍNEZ A, ROJAS N, GARCÍA L, GONZÁLEZ F, DOMÍNGUEZ M AND CATALÁN A. 2014. In vitro activity of terpenes against Candida albicans and ultrastructural alterations. Oral Surg Oral Med Oral Pathol Oral Radiol 118(5): 553-559.

MOSADIK MA, BANBURY L, FOSTER P, BOOTH R, MARKHAM J, LEACH D AND WATERMAN PG. 2004. Screening of some Australian Flacourtiaceae species for in vitro antioxidant, cytotoxic and antimicrobial activity. Phytomedicine 11: 461-466.

PEREIRA FG, COSTA FB, MARQUETE R, MAY B, FALCÃO DQ, MANSUR E, MOREIRA DL AND ROMANOS MTV. 2016. Anti-herpes activities of the pure and nanoemulsion of essential oil from leaves of Casearia sylvestris Sw. (Salicaceae). IJGHC 5 (2B): 112-121.

PEREIRA FG, MARQUETE R, LEITE KO, CABRAL OV, MAY B, MANSUR E AND MOREIRA DL. 2017. Anatomical aspects, chemical analysis and cytotoxic effect of the essential oil fromleaves of Casearia arborea (Salicaceae). Bol Latinoam Caribe Plant Med 16(2): 99-109.

PFALLER MA. 2012. Antifungal drug resistance: mechanisms, epidemiology and consequences for treatment. Am J Med 125.

PFALLER MA AND DIEKEMA DJ. 2004. Twelve years of fluconazole in clinical practice: global trends in species distribution and fluconazole susceptibility of bloodstream isolates of Candida. Clin Microbiol Infect 10(Suppl. 1): 11-23.

PFALLER MA AND DIEKEMA DJ. 2007. Epidemiology of invasive candidiasis: a persistent public health problem. Clin Microbiol Rev 20: 133-163. 
PFALLER MA, DIEKEMA DJ, GIBBS DL, NEWELL VA, NAGY E, DOBIASOVA S, RINALDI M, BARTON R AND VESELOV A. 2008. Candida krusei, a multidrugresistant opportunistic fungal pathogen: geographic and temporal trends from the ARTEMIS DISK Antifungal Surveillance Program, 2001 to 2005. J Clin Microbiol 46: 515-521.

PFALLER MA, MESSER SA, BOYKEN L, RICE C, TENDOLKAR S, HOLLIS RJ, DOERN GV AND DIEKEMA DJ. 2005. Global trends in the antifungal susceptibility of Cryptococcus neoformans (1990 to 2004). J Clin Microbiol 43: 2163-2167.

PINTO AZL, DE ASSIS AFS, PEREIRA AG AND PASA MC. 2013. Levantamento etnobotânico de plantas medicinais comercializadas no mercado do Porto em Cuiabá, Mato Grosso, Brasil. Flovet 5: 51-70.

PROCOP GW AND ROBERTS GD. 2004. Emerging fungal diseases: the importance of the host. Clin Lab Med 24: 691-719.

RELLA A, FARNOUD AM AND DEL POETA M. 2016. Plasma membrane lipids and their role in fungal virulence. Prog Lipid Res 61: 63-72.

ROGERS PD AND BARKER KS. 2003. Genome-wide expression profile analysis reveals coordinately regulated genes associated with stepwise acquisition of azole resistance in Candida albicans clinical isolates. Antimicrob Agents Chemother 47: 1220-1227.

SABULAL B, DAN M, JOHN A, KURUP R, PRADEEP NS, VALSAMMA RK AND VARUGHESE G. 2006. Caryophyllene-rich rizome oil of Zingiber nimmonii from South India: Chemical characterization and antimicrobial activity. Phytochemistry 67(22): 2469-2473.

SANGLARD D AND BILLE J. 2002. Current understanding of the modes of action of and resistance mechanisms to conventional and emerging antifungal agents for treatment of Candida infections. In: Calderone RA (Ed), Candida and candidiasis. ASM Press, Washington, DC, p. 349-383.

SARPIETRO MG, DI SOTTO A, ACCOLLA ML AND CASTELLI F. 2015. Interaction of $\alpha$-caryophyllene and $\alpha$-caryophylleneoxide with phospholipidbilayers: Differential scanning calorimetrystudy. Thermochim Acta 600: 28-34.

SATO MEO, LUZ SFB AND AQUINI Y. 1996. Estudos farmacológicos das folhas de Casearia sylvestris Sw. (Flacourtiaceae). In. Congresso Nacional de Botânica. Nova Friburgo, Rio de Janeiro. Resumo SBB, p. 246.
SIKKEMA J, BONT JAM AND POOLMAN B. 1995. Mechanisms of membrane toxicity of hydrocarbons. Microbiol Rev 59: 201-222.

SILVA SL, CHAAR JS, FIGUEIREDO PMS AND YANO T. 2008. Cytotoxic evaluation of essential oil from Casearia sylvestris Sw. on human cancer cells and erythrocytes. Acta Amaz 38(1): 107-112.

SLEUMER HO. 1980. Flora Neotropica Monograph n.22 (Flacourtiaceae). New York: The New York Botanical Garden.

SOUSA FG, SCHNEIDER FZ, MENDES CE, MOURA NF, DENARDIN RBN, MATUO R AND MANTOVANI MS. 2007. Clastogenic and anticlastogenic effect of the essential oil from Casearia sylvestris Swartz. J Essent Oil Res 19: 376-378.

STEFANELLO MEA, WISNIEWSKI JA, SIMIONATTO EL AND CERVI AC. 2010. Essential Oil Composition of Casearia decandra Jacq. J Essent Oil Res 22(2): 157-158.

TININIS AG, ASSONUMA AA, TELASCREA M, PEREZ CC, SILVA MRSRM, FAVORETO R AND CAVALHEIRO AJ. 2006. Composição e variabilidade química de óleo essencial de Casearia sylvestris Sw. Rev Bras Pl Med Botucatu 8(4): 132-136.

TOMAZI LB, AGUIAR PA, CITADINI-ZANETTE V AND ROSSATO AE. 2014. Estudo etnobotânico das árvores medicinais do Parque Ecológico Municipal José Milanese, Criciúma, Santa Catarina, Brasil. Rev Bras Plantas Med 16(2): 450-461.

VANDENDOOL H AND KRATZ PD. 1963. A generalization of the retention index system including linear temperature programmed gas-liquid partition chromatography. J Chromatogr A11: 463-471.

XIE C, SUN L, MENG L, WANG M, XU J, BARTLAM M AND GUO Y. 2015. Sesquiterpenes from Carpesium macrocephalum inhibit Candida albicans biofilm formation and dimorphism. Bioorg Med Chem Lett 25(2): 5409-5411.

ZUZARTE M, GONÇALVES MJ, CAVALEIRO C, VALESILVA L, SILVA MJ, PINTO E AND SALGUEIRO L. 2011. Chemical composition and antifungal activity of the essential oils of Lavandula viridis L'Hér. J Med Microbiol 60: 612-618.

\section{SUPPLEMENTARY MATERIAL}

Table SI - Chemical Composition of the Essential Oil from Fresh Leaves of Casearia sylvestris (Jun /2014) and their respectively fractions. 